\title{
Parents' experiences of universal screening for haemoglobin disorders: implications for practice in a new genetics era
}

\author{
Louise Locock and Joe Kai
}

\author{
ABSTRACT \\ Background \\ England is the only country in the world that currently \\ has universal population screening for haemoglobin \\ disorders through linked antenatal and newborn \\ screening. Little is known about the acceptability of \\ such screening.
}

Aim

To explore parents' experiences of, and attitudes towards, new universal genetic screening for haemoglobin disorders.

Design of study

Narrative interview study.

Setting

Primary and community care settings across England.

\section{Method}

Narrative interviews were undertaken with a maximum variation sample of 39 people who had experienced gene-carrier identification through antenatal and newborn screening for sickle cell, thalassaemia, and other haemoglobin variants within the previous 2 years.

Results

Most parents were unaware screening had occurred or had given it little consideration and so were surprised or shocked by results. However, they were glad to learn of their carrier status, reproductive genetic risk, or their newborn's carrier status. Participants emphasised that antenatal screening should happen as early as possible. Many would rather have known their carrier status before pregnancy or before entering a relationship. Although most were satisfied with the information they received, significant misunderstandings remained. There were culturally diverse attitudes towards prenatal diagnosis and termination. These procedures were acceptable to some parents with strong religious beliefs, including Christians and Muslims.

\section{Conclusion}

Parents support screening for haemoglobin disorders but need to be better informed and better prepared for results and what they mean. Sensitivity to patient diversity in attitudes and choices is also required. Universal screening for genetic reproductive risk will increasingly involve generalists, particularly in primary care, presenting opportunities for screening before or earlier in pregnancy, which is likely to be welcomed by patients.

\section{Keywords}

genetic screening; sickle cell; thalassaemia.

\section{INTRODUCTION}

Sickle cell disorders and beta thalassaemia major are recessively inherited disorders affecting the structure or quantity of haemoglobin respectively. They are potentially life threatening, causing anaemia and a range of disabling morbidity. Sickle cell disorders are most common among people of African origin. Thalassaemias are more common among individuals originating from the Mediterranean, Indian subcontinent, and the Middle and Far East. However, haemoglobin gene variants may occur in any ethnic group, and this is now more common with greater ethnic diversity in relationships. There are an estimated 637000 carriers of haemoglobin gene variants in England (1.2\% of the whole population, and up to $25 \%$ of people in some ethnic groups). The most common haemoglobin gene variants are $\mathrm{Hb} \mathrm{S}$ (sickle cell), $\mathrm{Hb} \mathrm{C}$, $\mathrm{Hb}$ beta thalassaemia, $\mathrm{Hb} \mathrm{E}$ and $\mathrm{Hb}$ D Punjab.

Global population movement and mixing mean haemoglobin disorders are increasingly common in countries of Northern Europe and the US, where they were not previously endemic. Haemoglobin disorders and cystic fibrosis are now the most common recessively inherited disorders in the UK. People who carry a gene variant for one of these conditions are healthy, but can have an affected child if their partner is a carrier of the same condition.

Internationally, ad hoc screening for haemoglobin disorders is the most common model of diagnosis, but more systematic antenatal carrier screening occurs

L Locock, MPhil, PhD, university research lecturer, Department of Primary Care, University of Oxford, Oxford. J Kai, FRCGP, professor of primary care, University of Nottingham, Nottingham.

Address for correspondence

Louise Locock, DIPEx Research Group, Department of Primary Care, University of Oxford, Old Road Campus, Headington, Oxford OX3 7LF.

E-mail: louise.locock@dphpc.ox.ac.uk

Submitted: 13 July 2007; Editor's response: 25 October 2007; final acceptance: 15 January 2008.

(c)British Journal of General Practice 2008; 58: 161-168.

DOI: $10.3399 /$ bjgp08X277276 


\section{How this fits in}

Little is known about the acceptability of universal population screening for haemoglobin disorders using linked antenatal and newborn screening programmes. This study suggests parents need to be better informed about such screening, and better prepared for the potential results. Some parents had significant misunderstandings about their carrier status and genetic reproductive risk, raising doubts about the effectiveness of information and communication offered to them. Parents show considerable diversity in their attitudes and choices in relation to screening, including prenatal diagnosis and termination of pregnancy. They support earlier screening, preconception.

within Southern European countries such as Greece, Italy, and Cyprus, and newborn screening for affected children occurs in the US and France. Iran has mandatory premarital screening. However, England is the only country in the world to have universal screening for sickle cell, beta thalassaemia, and other haemoglobin gene variants by linked antenatal and newborn screening programmes (Box 1).

This marks a shift from a traditional model of diagnosis of individuals affected by genetic disorders toward the screening of populations. The former has involved specialised genetic services. In contrast,

\section{Box 1. Screening for sickle cell disorders and thalassaemia.}

- Antenatal screening

- As part of antenatal screening in England, all pregnant women are now screened for thalassaemias (using microcytosis, detected by routine full blood count).

- In high-prevalence (fetal prevalence of sickle cell of $>1.5 / 10000$ pregnancies) areas every pregnant woman is also offered screening to see if she is a carrier of a sickle cell or other haemoglobin variant. In lower-prevalence areas this test is offered according to ancestry using a standard family origin questionnaire.

- There is a 1:4 risk of having an affected baby in each pregnancy if both parents are carriers.

- When a pregnant woman is found to be a carrier, the baby's father should be offered testing as soon as possible. The earlier in pregnancy that a couple 'at risk' is identified, the more time both individuals have to be referred for specialist counselling and to make choices about the pregnancy, and whether or not they want a prenatal diagnosis.

- Newborn screening

- Newborn screening for sickle cell disorders is now offered for all babies as part of the newborn bloodspot test in England. This is for the early identification of children affected with these disorders. However, an estimated 9000 babies per year who are healthy carriers will also be identified by the test.

- Newborn blood spot screening for cystic fibrosis across England is not yet fully implemented and differs from screening for sickle cell disorders. Testing for cystic fibrosis avoids carrier identification, so carrier numbers detected are very low, carriers identified have a small risk of developing the condition, and screening is not preceded by antenatal screening.

Source: www.pegasus.nhs.uk

For further information on the NHS screening programme see www.sickleandthal.org.uk population screening will require provision of information and explanation, particularly for people identified as gene carriers, by those in the 'frontline' of health care without specialist genetic expertise, such as midwives and physicians in primary, maternal, and child health care. It has been suggested that GPs may feel they lack relevant knowledge, skills, or confidence to contribute effectively to new genetic services, ${ }^{1-3}$ but this will increasingly become a routine part of their work. Practitioners must be sufficiently informed to support pregnant women identified as carriers, and the parents of those babies identified as carriers. The aim of this study was to explore the experiences of parents offered new universal screening for haemoglobin disorders in order to inform clinical practice.

\section{METHOD}

The study was conducted as part of the DIPEx research project into personal experiences of health and illness, based at the University of Oxford. In line with established DIPEx methodology a maximum variation sample ${ }^{4}$ was sought nationally, seeking variation across demographic factors as well as types of screening and diagnostic experiences. The aim of maximum variation sampling is to seek a broad range of experiences and identify differences as well as commonalities between groups and individuals. Participants were recruited through GPs and midwives, haematologists, genetic counsellors, specialist sickle cell and thalassaemia counsellors, and local and national support groups. Practitioners and support-group leaders were sent information about the project and copies of the information pack to hand out to potential participants. Those interested in taking part could either contact the researcher direct or give permission for their contact details to be passed to the researcher.

Thirty-nine people participated (including eight couples and one woman interviewed with her sisterin-law). Of these, 30 had experience of gene-carrier identification through antenatal screening and nine through newborn screening. Their characteristics, based on self-assigned ethnicity, are detailed in Table 1.

In-depth narrative interviews were conducted either in the person's own home or elsewhere if preferred. Narrative interviewing empowers people to identify the issues that matter to them, in their own words, rather than being constrained by the language and priorities of professionals. Prompts were used after the initial narrative to elicit information about specific topics, such as attitudes to disability and termination, attitudes to risk and understanding of inheritance, if they had not already been covered. Interviews were videotaped or audiotaped and transcribed verbatim.

Nine responders were interviewed in languages 
other than English (three Mirpuri, two Urdu, two French, one Portuguese, and one Sylheti) by experienced qualitative health researchers with one of the authors in attendance. This approach enabled those interviewed in other languages to offer a full and uninterrupted narrative, which would have been constrained had interpreters been used. Transcription and translation were undertaken by the researchers who conducted the interviews. These researchers also assisted with recruitment and consent procedures.

Participants could review their transcript (or a video or audio copy of the interview) and remove any sections with which they were unhappy. Eight participants requested minor changes to remove comments about other people or correct their English.

The interviews were coded and analysed thematically ${ }^{5}$ using N6 computer-assisted qualitative data analysis software. The coding framework was developed using a modified grounded theory approach, ${ }^{6}$ drawing on both emergent and anticipated themes from existing theory and research evidence, particularly on minority ethnic experiences of healthcare, patient decision-making, informed choice and consent, and lay understanding of risk. The attention to emergent themes again gives prominence to the perspectives of service recipients.

Data relevant to professional practice were identified and analysed. The coding framework and the thematic analysis were reviewed by a multidisciplinary advisory panel of experts on haemoglobinopathies. Summaries of the analysis and clips from the interviews can be seen at www.dipex.org/sicklecellandthalassaemia.

\section{RESULTS}

\section{Being informed about screening}

A minority of participants had actively requested carrier screening, either before or during pregnancy, but for most it occurred or was offered automatically during pregnancy. Many saw it as a routine blood test and some incorrectly believed it was mandatory. They had neither actively considered its implications nor expected results of any consequence. As one father explained:

'There was a leaflet but I just didn't take it seriously. I didn't understand.' (Appendix 1, Example 1)

Newborn screening for sickle cell disorders has been included in the heel prick test, long established in screening for phenylketonuria and congenital hypothyroidism. Again, many parents had not fully understood what the heel prick test was for. Immediately after birth, some parents found it difficult to absorb information about newborn screening. One mother explained she had other priorities following a difficult labour and some problems with the baby's health, and the screening result was wholly unanticipated:

'We probably did have leaflets. And I think if we'd had a nice delivery ... it might have been different. But we, it's just one thing we didn't give a thought to.' (Appendix 1, Example 2)

Responders would have liked to be more informed about screening, although it was unclear whether being asked for explicit consent was a particular issue. Even when people had not fully understood the test, virtually all were glad to have been made aware that they or their baby were carriers and recommended it to other parents. One exception was a mother who agreed to have prenatal diagnosis by chorionic villus sampling when she and her husband were identified as beta thalassaemia carriers. She has since regretted this and believed the procedure itself (which had to be repeated) may somehow have caused her child's beta thalassaemia major (Appendix 1, Example 3).

\section{Timing of screening tests}

While the opportunity to have antenatal screening

Table 1. Characteristics of sample.

\begin{tabular}{|c|c|c|c|c|c|}
\hline Family origin & Parental variants ${ }^{a}$ & Religion & Female & Male & Total \\
\hline $\begin{array}{l}\text { African/ } \\
\text { African-Caribbean }\end{array}$ & $\begin{array}{l}10 \text { carriers of } \mathrm{Hb} \mathrm{S} \\
1 \text { carrier of } \mathrm{Hb} \mathrm{C} \\
2 \text { parents with a } \\
\text { sickle cell disorder } \\
2 \text { not carriers }\end{array}$ & $\begin{array}{l}8 \text { Christian } \\
1 \text { Muslim } \\
6 \text { no religion/ } \\
\text { unspecified }\end{array}$ & 13 & 2 & 15 \\
\hline $\begin{array}{l}\text { Indian } \\
\text { sub-continent }\end{array}$ & $\begin{array}{c}8 \text { carriers of } \mathrm{Hb} \\
\text { beta thalassaemia } \\
\text { carrier of Hb D Punjab } \\
1 \text { status unknown }{ }^{b}\end{array}$ & $\begin{array}{l}9 \text { Muslim } \\
1 \text { Sikh }\end{array}$ & 9 & 1 & 10 \\
\hline European & $\begin{array}{c}5 \text { carriers of } \mathrm{Hb} \\
\text { beta thalassaemia } \\
1 \text { carrier of } \mathrm{Hb} \mathrm{S} \\
1 \text { not a carrier } \\
1 \text { status unknown }\end{array}$ & $\begin{array}{l}2 \text { Christian } \\
6 \text { no religion/ } \\
\text { unspecified }\end{array}$ & 4 & 4 & 8 \\
\hline Far East & $\begin{array}{c}2 \text { carriers of } \mathrm{Hb} \mathrm{E} \\
1 \text { carrier of } \mathrm{Hb} \\
\text { beta thalassaemia }\end{array}$ & $\begin{array}{l}1 \text { Buddhist } \\
2 \text { no religion } \\
\text { /unspecified }\end{array}$ & 2 & 1 & 3 \\
\hline Mixed $^{c}$ & $\begin{array}{c}2 \text { carriers of } \mathrm{Hb} \mathrm{S} \\
1 \text { not a carrier }\end{array}$ & $\begin{array}{l}3 \text { no religion/ } \\
\text { unspecified }\end{array}$ & 2 & 1 & 3 \\
\hline Total & & & 30 & 9 & 39 \\
\hline \multicolumn{6}{|c|}{ 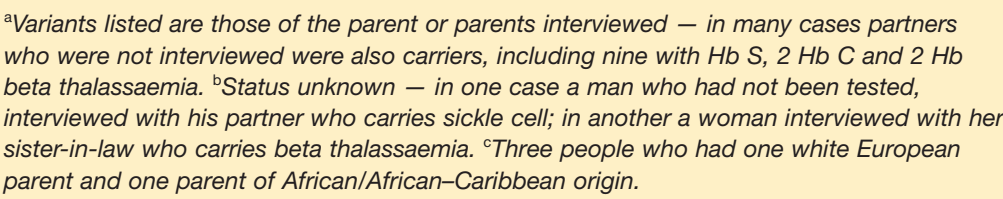 } \\
\hline
\end{tabular}


was valued, many participants would rather have known their carrier status before becoming pregnant or choosing a partner. Some said they might not have started a relationship if they had known they were both carriers. This was true across a range of different faith groups and cultural backgrounds. As one mother said, 'If I had known right from the start that I was a carrier, I would have taken more care over my partner. I think I would have chosen a different partner.' (Appendix 2, Examples 1). Some participants from communities where arranged marriage is customary agreed that telling another family your son or daughter carries a genetic condition may be socially difficult (Appendix 2, Example 3).

However, most still thought it was better to be open about carrier status and that both potential partners should be screened before finalising an arranged marriage. Although they might not have had this opportunity themselves, they intended to make sure any of their own children who were carriers did not marry another carrier:

'They should have their son or daughter tested, and my message is that before planning their future, have blood tests... Like if I say to you I want to arrange my daughter's marriage, then I should say to you that "My daughter has thalassaemia [is a carrier], we should tell them before marriage".' (Appendix 2, Example 4)

Other participants said they would still have got married if they had known they were both carriers, but might have tried not to get pregnant or would have had prenatal diagnosis.

Within pregnancy, early screening and diagnosis was felt to be important. Some people felt they could only consider a termination early in pregnancy, whether for personal, emotional, or religious reasons. Some Islamic scholars teach that termination for lifethreatening conditions is permitted up to 120 days of pregnancy, at which point the soul enters the unborn baby ('ensoulment'). For some women this made the timing of screening and diagnosis vital, although not all Muslim parents were aware of or agreed with this teaching:

'The Molvies [priests] sit on Radio Ramadan when it opens and they said that Mashallah [God has willed it]. Yes, if it's more than this many weeks, then it is not permitted ... But it's not a sin under 3 months, or up to 3 months ... Have it checked within 11 weeks, and yes, if your child is major, then have a miscarriage [termination]. Nothing will happen. Eleven weeks is nothing, I mean, the soul has not entered the child yet, so it's not hard.' (Appendix 2, Example 5)
Others would still have considered a termination later on, but felt the longer they had to wait the more distressing it would be. A father said about waiting for amniocentesis results:

'Every single day that you're waiting, you felt, "Oh, my God, this is such a precious thing." So you feel more attached, and therefore if the termination does come, it would be even more painful.' (Appendix 2, Example 6).

\section{Understanding carrier status and genetic risk}

Most participants felt they were given good information to help them understand how genes are passed on, and particularly valued drawings or diagrams to demonstrate inheritance. However, many individuals worried at first that they or their baby were seriously ill when carrier status was identified (Appendix 3, Example 1). Some people appeared to have misunderstood the information provided or had added their own meanings or interpretations. Several people who knew they were carriers used expressions such as 'I've got thalassaemia - but it's not major'. One mother thought her daughter as a carrier had 'less blood from one side', and another thought one parent had 'good blood' and the other 'bad blood'. One woman believed being a thalassaemia carrier was something she caught 'because of dirt' (Appendix 3).

Achieving partner testing was influenced by people's assumptions about its relevance according to ethnic origin and the asymptomatic nature of being a carrier. Some participants were unaware that haemoglobin disorders could affect people of any ethnic origin, thus two women of African origin with white partners had not thought their partner needed to be screened. A white British man who learned as a child that he was a beta thalassaemia carrier had been advised that 'you shouldn't marry a Greek girl', so it was a shock when his English wife turned out to be a carrier.

Several women found it difficult to persuade the baby's father to be tested, either because he did not believe it was possible that he could be a carrier or because he was anxious about the test and needles, or both. Some men felt sure they were not carriers because they were fit and healthy, and told their partners they did not need to be screened (Appendix 4, Example 1). One white woman touched upon issues of non-paternity potentially being raised by screening when her baby was found to be a sickle cell carrier. She thought her white husband might have assumed she had been unfaithful:

'... if he wasn't as understanding, if he wasn't as good a man as what he is, then I dread to think ... 
I could have been black and blue by now and out that door with a newborn baby, nowhere to go'. (Appendix 4, Example 2)

Participants varied in their understanding and perception of risk of having an affected pregnancy. Most understood that the risk of two carriers having an affected child was one in four, but others recalled the risk as less or greater than this. Even among those who clearly understood the risk of having an affected child was one in four, this meant different things. A mother with haemoglobin sickle cell disorder whose partner was a sickle cell carrier described her optimistic outlook, comparing her onein-four risk of having a baby with sickle cell anaemia to the risk of being knocked down by a car (which is, in fact, many times lower). A couple who were both sickle cell carriers declined prenatal diagnosis because they believed their strong Christian faith would protect the baby. In contrast an Italian couple, both thalassaemia carriers, felt preimplantation genetic diagnosis was the only option open to them as Catholics who would not consider termination. The man's sister had died of beta thalassaemia major and he regarded a one-in-four risk as unacceptably high, comparing it to placing the baby in one lane of a four-lane carriageway and waiting for a car to come along (Appendix 4, Example 3).

\section{Communication of carrier results and advice about options}

Most newborn results were sent by letter. Antenatal results were more commonly given by telephone, although some were posted. Participants felt there was no ideal way to learn that they or their baby carried a genetic disorder, but receiving a letter was distressing, especially if people were not really aware they had been screened - as one white woman said:

'I didn't know I was actually being tested for that ... and then I had a letter saying that I had the beta thalassaemia trait ... I was terrified, I didn't know what it was all about.' (Appendix 5, Example 1).

A phone call could still be a shock, but it was seen as preferable to receiving a letter. As one mother explained, 'If you've got that person on the line, you can actually ask questions straightaway' (Appendix 5, Example 2), and thereby find out more details and be reassured.

For people whose first language was not English, this posed an additional barrier to understanding their screening results. Some Urdu and Mirpuri speakers interviewed were pleased they had been able to speak to a specialist counsellor in their own language. However, others sought information and counselling in their own language with less success.

Most people at risk of an affected pregnancy felt positive about how the options for prenatal diagnosis and continuing or ending the pregnancy were presented. Most felt the professionals involved, particularly specialist counsellors, had been nondirective. Some disliked the loneliness of decisionmaking in this situation and 'sort of wished that somebody had given us a guiding hand, because it was so hard to decide' (Appendix 5, Example 3), although a few felt counselling had been too directive (Appendix 5, Example 4).

Some people wanted to 'know the worst' about the conditions and all possible complications, while others felt staff could have given them more hope and a positive picture of them and their children managing successful lives with the conditions. Some responders wanted to know every detail about termination early on, while others were distressed that this might be a possibility. One father summed up the importance of health professionals exploring and being led by individual preference:

'I think I tried to prod them in a way, and say, you know, "If I have to go to termination, what is the steps?" They tried to be nice in a way, they tried not to go down that route ... I think they were trying to be neutral, but in a way if the patients want to know, then they should give us the whole works rather than shield us.' (Appendix 5, Example 5)

\section{Religious influences on individual decision making}

In making decisions, participants were influenced by a range of personal, cultural, social, and religious values. Some people with strongly-held religious beliefs declined prenatal diagnosis, feeling that every human life is sacred and they should not question God's will for them. This group included both Christian and Muslim parents. Others were willing to accept screening, and to consider diagnostic tests in pregnancy so they could prepare themselves, even if they would not consider termination. Again, parents of both Christian and Muslim origin took this view.

Some participants described a sense of resignation to God's plan for them or positively embracing the challenge. One Pakistani Muslim mother said:

'There wasn't any point in getting checked, because neither did we want to have a termination and neither did we think there was any point ... I left it to Allah ... The individual cannot do anything ... If we'd have terminated, then we 
wouldn't have our daughter. He [husband] says, "Okay, our daughter is troubled, but Allah has given her these troubles, and at least she is in front of our eyes." We don't have to regret that we terminated her.' (Appendix 6, Example 2)

\section{An African Roman Catholic mother said:}

'... in life everyone has their crosses to bear. My first son, I've taken him up as my cross ... and in the life that I travel with him I can see the life of Christ.' (Appendix 6, Example 4)

The fact that a range of opinions can be seen across different faith groups means one cannot predict religious fatalism or acceptance on the basis of faith group. Further examples are shown in Appendix 6.

Strong faith was clearly a dominant force in some parents' decision making around screening and restricted what they perceived as the choices available to them. However, women of both Christian and Muslim faith were willing to consider termination. Some Muslim mothers wanted others to know that termination may be permissible within Islam under certain conditions, thereby providing a choice consistent with strong faith (see the section on 'Timing of tests'). For those Christian parents willing to consider termination, it was more a question of weighing up Christian objections to termination against other factors that were important to them, especially not wanting their baby to suffer.

People of other faiths or no strong religious convictions also described a process of balancing concerns about the baby, their moral values, and their own feelings as parents. This included a Buddhist couple who chose amniocentesis and felt they would definitely have terminated if the baby had beta thalassaemia major, and a Sikh woman whose husband was not a carrier, who thought she would have continued the pregnancy and declined prenatal diagnosis. This was more for personal than religious reasons, however:

'I wouldn't say it was religious. It was more just us, the way we think. Whereas our parents would be more religious, thinking, "Well you shouldn't terminate, full stop".'

The suggestion of generational difference is important; class and educational status may also have a bearing.

\section{DISCUSSION}

\section{Summary of main findings}

This study revealed the following main findings:
- Many people did not realise they were being screened or had not fully considered the implications, and were often shocked by the results.

- Most were glad to learn about their own or their child's carrier status.

- Communicating results by telephone or face-toface was preferred to receiving a letter.

- Many participants would prefer to be screened before conception or even before choosing a partner.

- Most felt it was important to be open about carrier status with potential partners.

- Partners need to appreciate they may still be carriers even though they are healthy, and regardless of ethnic origin.

- Some parents with strong religious faith may wish to consider prenatal diagnosis and perhaps termination of an affected pregnancy.

\section{Comparison with existing literature}

Green et al's review of the literature on the psychosocial aspects of genetic screening for pregnant women and newborns reports that most women in the general population hold positive attitudes towards antenatal screening for a range of conditions. ${ }^{7}$ Studies reviewed by Green et al suggest that around $80 \%$ of women would prefer to have the screening option rather than just the diagnostic test option, and that $60-75 \%$ of women believe prenatal testing can empower them to make informed choices and that it is a maternal responsibility to ensure the health of the baby. A smaller percentage (approximately 10\%) feel prenatal testing generates anxiety, medicalises pregnancy, and may stigmatise disability in society. However, there is substantial evidence that large gaps in women's knowledge exist and risk is not well understood.

There is less evidence on specific attitudes towards, and the acceptability of, haemoglobin disorder screening; ${ }^{8}$ available evidence comes largely from the US. ${ }^{9-12}$ This and other work suggests that women may not be adequately informed about the purpose of screening tests and the nature of inherited risk, and that language problems may compound the already difficult task of gaining informed consent and explaining recessive inheritance..$^{13,14}$ The current study's findings reinforce this evidence.

Although responders wanted to be more informed about screening, it was unclear whether being asked for their consent was a particular issue. This is consistent with a recent study of Pakistani women. ${ }^{15}$ Obtaining informed consent for several antenatal and newborn screening tests may not be achievable in practice, where a blurring may occur between being told a test is being undertaken and gaining explicit consent. ${ }^{15,16}$ 
The current study's findings suggest personal communication of results was preferred to a letter. There is little previous evidence on acceptable and effective methods of communicating carrier status and more research is needed..$^{17,18}$

Previous research has suggested that people are reluctant to disclose carrier status when arranging marriages. ${ }^{19-21}$ This study's findings differ significantly; many of the responders wanted to know about carrier status before choosing a partner and recommended openness.

These findings emphasise the need to avoid assumptions about attitudes to prenatal diagnostic testing, termination, or having an affected child.22-26 Regardless of attitudes to termination, prenatal testing can reduce anxiety if the fetus is unaffected, or allow parents to prepare for an affected pregnancy and best plan care for both their child and their own support. Raising awareness of Islamic teaching on termination might also help. ${ }^{20,24,27}$ Previous work has found the main reason parents of Pakistani origin had comparatively lower use of prenatal diagnosis ${ }^{28}$ was not Muslim objection to termination but, rather, inequality in service delivery. Screening was not undertaken or timely choices and options were not provided. ${ }^{29}$ Like others, ${ }^{22}$ this study found that a diagnostic test offered later in pregnancy may be unacceptable. The increasing use of chorionic villus sampling early in pregnancy is likely to make prenatal diagnosis more popular across all communities. .,30 $^{3}$

Although more research into the perspectives of particular cultural or faith groups can raise awareness of concerns that are specific to those groups, it is important to bear in mind that this cannot be predictive of individual attitudes.

\section{Strengths and limitations of the study}

Narrative interviews offer participants a chance to explore in depth their attitudes and experiences. This sample included people from a wide range of ethnic, cultural, religious, and linguistic backgrounds, to provide a breadth of perspectives. Unlike earlier work prior to universal screening across England, ${ }^{13,14,22}$ individuals of European origin were included. However, the numbers in each category were relatively small and further research with particular groups is desirable to give greater depth and nuance to the range of perspectives identified here.

A maximum variation sample in terms of screening experience was sought, and largely achieved, but did not find any participants who declined all screening. Nevertheless, accounts of partners refusing screening and parents declining prenatal diagnostic testing were included.

It was not possible to include experience of the early diagnosis of children affected by sickle cell disorders following universal newborn screening, given its recent implementation and within the confines of the study period. However, the sample does include those with children affected by haemoglobin disorders diagnosed before universal newborn screening was in practice.

\section{Implications for clinical practice}

This study highlights issues of growing importance for practitioners, with or without specialist genetics expertise, in primary, maternal, and child healthcare. The challenges are described below.

Timely provision of information. Specific written prescreening information is now available for England (www.sickleandthal.org.uk). Providing similar information about newborn screening during pregnancy (www.ich.ucl.ac.uk/newborn), as well as at the time of the test, might help prepare parents for possible results. ${ }^{16}$

Raising general awareness of these conditions and earlier screening among adults of reproductive age. Provision of information and carrier testing before pregnancy appears feasible in primary care cr,32 $^{31}$ and is supported by parents' perspectives here. This could ideally feature more routinely in future. It would also help to reduce 'information overload' and the need to explore such screening in pregnancy itself at a generally positive time for parents. Nevertheless, opportunities still exist for earlier screening when women first notify pregnancy, usually to a primary care practitioner. This is currently under investigation (www.controlled-trials.com/ISRCTN00677850).

Explaining the results. Primary and community staff may be the first port of call for people seeking further information after being told they are a carrier. Increasingly, with universal screening, people who have no prior knowledge or family history of haemoglobin disorders will discover they are carriers. The range of misunderstandings about carrier status among some responders raises doubts about the adequacy and effectiveness of information and communication offered to them. Practitioners must be able to explain the distinction between being a healthy carrier and having the condition, how recessive inheritance works, and why partner screening is recommended, regardless of ethnic origin.

Advice about choices. Generalist professionals should be familiar with the trajectory patients are likely to follow if identified as at risk. They should know where to refer patients promptly for partner testing or specialist counselling about options and prenatal diagnosis, according to local protocols. In 
doing so, it is important to be sensitive to individual diversity in attitudes and choices, and to avoid cultural or religious assumptions.

GPs perceive genetic service development as relevant to primary care $^{32}$ and the generalist approach, ${ }^{33}$ but may feel ill-equipped to provide basic advice to those at genetic risk. ${ }^{2}$ Specific resources are becoming available to help health professionals across disciplines with this new challenge (www.pegasus.nhs.uk/frontline/menu.htm and www.chime.ucl.ac.uk/APoGl).

\section{Funding body}

The study on which this article draws was funded by the NHS Sickle Cell \& Thalassaemia Screening Programme on behalf of the National Screening Committee. The authors' work was independent of the funders

\section{Ethical approval}

The DIPEx research group has full MREC approval for its studies (reference 03/5/016) (all adult health conditions). Participants see a copy of their interview transcript and remove any material they do not want made publicly available, before giving DIPEx copyright for their words to be used in broadcasting, research, teaching, and publication

\section{Competing interests}

Louise Locock declares no competing interests. Joe Kai is academic lead for PEGASUS, a national initiative to support health professional screening for haemoglobin disorders, funded by the NHS Sickle Cell \& Thalassaemia Screening Programme on behalf of the National Screening Committee

\section{Acknowledgements}

The authors wish to thank all the people who took part in interviews; the funders; members of the project advisory panel; clinicians and support group staff who helped recruit; researchers interviewing in other languages (Shenaz Ahmed, Rubina Rahman, Huguette Comerasamy, and Isabel Lima); and Bernadette Modell. The Department of Primary Health Care at the University of Oxford is part of the NIHR School of Primary Care Research.

\section{Discuss this article}

Contribute and read comments about this article on the Discussion Forum: http://www.rcgp.org.uk/bjgp-discuss

\section{REFERENCES}

1. Watson E, Mayall E, Chapple J, et al. Screening for carriers of cystic fibrosis through primary health care services. BMJ 1991; 303(6801): 504-507.

2. Qureshi N, Armstrong S, Modell B. GPs' opinions of their role in prenatal genetic services: a cross-sectional survey. Fam Pract 2006; 23(1): 106-110.

3. Qureshi N, Modell B, Modell M. Timeline: raising the profile of genetics in primary care. Nat Rev Genet 2004; 5(10): 783-790.

4. Coyne IT. Sampling in qualitative research. Purposeful and theoretical sampling; merging or clear boundaries? J Adv Nurs 1997; 26(3): 623-630.

5. Ziebland S, McPherson A. Making sense of qualitative data analysis: an introduction with illustrations from DIPEx (personal experiences of health and illness). Med Educ 2006; 40(5): 405-414.

6. Pope C, Ziebland S, Mays N. Analysing qualitative data. In: Pope C, Mays N, eds. Qualitative research in health care. (3rd edn). Oxford: Blackwell Publishing and BMJ Books, 2006: 63-81.

7. Green JM, Hewison J, Bekker HL, et al. Psychosocial aspects of genetic screening of pregnant women and newborns: a systematic review. Health Technol Assess 2004; 8(33): iii, ix-x, 1-109.

8. Davies SC, Cronin E, Gill M, et al. Screening for sickle cell disease and thalassaemia: a systematic review with supplementary research. Health Technol Assess 2000; 4(3): i-v, 1-99.
9. Rowley PT, Loader S, Walden M. Pregnant women identified as hemoglobinopathy carriers by prenatal screening want genetic counselling and use information provided. Birth Defects Orig Artic Ser 1988; 23(5B): 449-454.

10. Rowley PT, Loader S, Sutera CJ, et al. Prenatal screening for hemoglobinopathies III. Applicability of the health belief model. Am J Hum Genet 1991; 48(3): 452-459.

11. Loader S, Sutera CJ, Walden M, et al. Prenatal screening for hemoglobinopathies II. Evaluation of counselling. Am J Hum Genet 1991; 48(3): 447-451.

12. Rowley PT, Loader S, Sutera CJ, et al. Prenatal screening for hemoglobinopathies I. A prospective regional trial. Am J Hum Genet 1991; 48(3): 439-446.

13. Green J, France-Dawson M. Women's experiences of routine screening during pregnancy: the sickle cell study. Targeting health promotion: reaching those in the West Midlands. In: Clarke A, Parsons E, eds. Culture, kinship and genes: towards cross-cultural genetics. New York: St Martin's Press, 1997: 120-132.

14. Dyson SM. Knowledge of sickle-cell in a screened population. Health Soc Care Community 1997; 5(2): 84-93.

15. Ahmed S, Green J, Hewison J. Antenatal thalassaemia carrier testing: women's perceptions of 'information' and 'consent'. J Med Screen 2005; 12(2): 69-77.

16. Parsons EP, King JT, Israel JA, Bradley DM. Mothers' accounts of screening newborn babies in Wales (UK). Midwifery 2007; 23(1): $59-65$.

17. Laird L, Dezateux C, Anionwu EN. Neonatal screening for sickle cell disorders: what about the carrier infants? BMJ 1996; 313(7054): 407-411.

18. Oliver S, Dezateux C, Kavanagh J, et al. Disclosing to parents newborn carrier status identified by routine blood spot screening. Cochrane Database Syst Rev 2004: 4: CD003859.

19. Rozario S. Genetics, religion and identity among British Bangladeshis: some initial findings. Diversity in Health and Social Care 2005; 2: 187-196.

20. Chattopadhyay S. 'Rakter dosh' - corrupting blood: the challenges of preventing thalassaemia in Bengal, India. Soc Sci Med 2006; 63(10): 2661-2673.

21. Ahmed S, Bekker H, Hewison J, Kinsey A. Thalassaemia carrier testing in Pakistani adults: behaviour, knowledge and attitudes. Community Genet 2002; 5(2): 120-127.

22. Atkin K, Ahmad WI, Anionwu EN. Screening and counselling for sickle cell disorders and thalassaemia: the experience of parents and health professionals. Soc Sci Med 1998; 47(11): 1639-1651.

23. Ahmed S, Green JM, Hewison J. Attitudes towards prenatal diagnosis and termination of pregnancy for thalassaemia in pregnant Pakistani women in the North of England. Prenat Diagn 2006; 26(3): 248-257.

24. Ahmed S, Saleem M, Sultana N, et al. Prenatal disagnosis of beta thalassaemia in Pakistan: experience in a Muslim country. Prenat Diagn 2000; 20(5): 378-383.

25. Atkin K, Ahmad W. Genetic screening and haemoglobinopathies: ethics, politics and practice. Soc Sci Med 1998; 46(3): 445-458.

26. Dyson S. Ethnicity and screening for sickle cell/thalassaemia. London: Elsevier, 2005.

27. Samavat A, Modell B. Iranian national thalassaemia screening programme. BMJ 2004; 329(7475): 1134-1137.

28. Modell B, Petrou M, Layton M, et al. Audit of prenatal diagnosis for haemoglobin disorders in the UK: the first 20 years. BMJ 1997; 315(7111): 779-784.

29. Modell B, Harris R, Lane B, et al. Informed choice in genetic screening for thalassaemia during pregnancy: audit from a national confidential enquiry. BMJ 2000; 320(7231): 337-341.

30. Greengross P, Hickman M, Gill M, et al. Outcomes of universal antenatal screening for haemoglobinopathies. J Med Screen 1999; 6(1): 3-10.

31. Modell M, Wonke B, Anionwu E, et al. A multidisciplinary approach for improving services in primary care: randomised controlled trial of screening for haemoglobin disorders. BMJ 1998; 317(7161): 788-791.

32. Watson E, Shickle D, Qureshi N, et al. The 'new' genetics and primary care: GPs' views on their role and their educational needs. Fam Pract 1999; 16(4): 420-425.

33. Kumar S, Gantley M. Tensions between policy makers and general practitioners in implementing new genetics: grounded theory interview study. BMJ 1999; 319: 1410-1413. 


\section{Appendix 1. Information and preparation for screening.}

- Example 1: 'There was a leaflet but I just didn't take it seriously. I didn't understand. "It couldn't happen to us", you know what I mean? Because we don't smoke, we don't drink, so, you know, we live a very healthy lifestyle. The implication of it all didn't really, didn't really hit us at all.' (Father of Vietnamese origin. Antenatal screening showed his partner carried beta thalassaemia and he carried haemoglobin E. Subsequent amniocentesis showed baby was unaffected.)

- Example 2: 'It was a shock when the letter come through the post. We knew obviously that they'd come and they'd done the test. But with everything else that went on in hospital - I mean we probably, we probably did have leaflets. And I think if we'd had a nice delivery and sort of, you know, a nice couple of days, then I don't know, it might have been different. But we, it's just one thing we just didn't give a thought to.' (White British mother with white partner. Baby identified as sickle cell carrier through newborn screening.)

- Example 3: 'I'm thinking that perhaps if we didn't have the checks [chorionic villus sampling], she would have been well. They poke you inside like this, when they put the needle in, it's a needle this big, a big one, they poke it into you two or three times. Then I didn't get tested three times [in three subsequent pregnancies], and all three sons are well. We are regretting that they did it twice, and she is like this because of that.' (Translated from Mirpuri. Mother of Pakistani origin and Muslim faith. First child has beta thalassaemia major.)

\section{Appendix 2. Timing of tests.}

- Example 1: 'If I had known right from the start that I was a carrier, I would have taken more care over my partner. I think I would have chosen a different partner. That's clear.' (Translated from French. Mother of Roman Catholic faith. Child has sickle cell anaemia. Neither partner knew they were carriers before the birth.)

- Example 2: 'If I could do a blood test before even getting pregnant that would be a different thing to me, you see? Because I would know myself that I can't have a child with someone who's got sickle cell ... You might be in love with the person but it's, at the end of the day, it's the child that will be suffering, not you two. So you have to choose who you really - be careful really to know.' (Mother of Congolese origin and Christian faith. Learnt through antenatal screening she was a sickle cell carrier, partner refused screening. Not aware she could have prenatal diagnosis. Baby diagnosed with sickle cell anaemia by newborn screening. Has since married new partner who had screening first - he is not a carrier.)

- Example 3: 'I had an arranged marriage. You know, you don't say you've got a disease and "We want to check you, you know, your son, if he's got it as well". You just went and got married. My mum was very much like, "Oh, well, don't say anything". And they feel that it's like a stigma that there's something bad. You've got something. You know, there's something wrong with you.' (Mother of Indian origin and Sikh faith. Discovered as a student she was a beta thalassaemia carrier. Husband tested during first pregnancy and is not a carrier.)

- Example 4: 'If one spouse has thalassaemia [is a carrier], then they should have their son or daughter tested, and my message is that before planning their future, have blood tests ... Like if I say to you I want to arrange my daughter's marriage, then I should say to you that "My daughter has thalassaemia [is a carrier], we should tell them before marriage. It's not a major condition. I have this condition too. So if you want, you should have your son tested as well. There could be a problem in their future".' (Translated from Urdu. Muslim mother of Pakistani origin, discovered she was a beta thalassaemia carrier in her first pregnancy, husband not a carrier.)

- Example 5: 'The Molvies [priests] sit on Radio Ramadan when it opens and they said that Mashallah [God has willed it]. Yes, if it's more than this many weeks, then it is not permitted ... But it's not a sin under 3 months, or up to 3 months. It's no sin, I mean, it's not alive. The soul enters at about 4 months ... Have it checked within 11 weeks, and yes, if your child is major, then have a miscarriage [termination]. Nothing will happen. Eleven weeks is nothing, I mean, the soul has not entered the child yet, so it's not hard. (Translated from Mirpuri. Mother of Pakistani origin and Muslim faith, has a son with beta thalassaemia major. Has since had prenatal diagnosis by chorionic villus sampling in every pregnancy.)

- Example 6: 'Every single day that you're waiting, you felt, "Oh, my God, this is such a precious thing". So you feel more attached, and therefore if the termination does come, it would be even more painful.' (Father of Vietnamese origin. Antenatal screening showed his partner carried beta thalassaemia and he carried haemoglobin E. Subsequent amniocentesis showed baby was unaffected.) 


\section{Appendix 3. Understanding carrier status.}

- Example 1: 'You think there's something wrong with your child. And you mention blood and you get panicky.' (White British mother with white partner. Baby identified as sickle cell carrier through newborn screening.)

- Example 2: 'We understood that one of us had got bad blood, as such, and one of us had got good blood.' (White British mother with white partner, baby identified as sickle cell carrier through newborn screening.)

- Example 3: 'Normal blood cells are round, aren't they? Whereas sickle cell blood cells are spiky. So that that hurts as it's going round your blood system.' (Mother of white British and Jamaican origin. Son identified as sickle cell carrier through newborn screening.)

- Example 4: 'I thought she [daughter who carries beta thalassaemia] will have less blood from one side, maybe that's why she doesn't eat.' (Translated from Urdu. Mother of Pakistani origin, identified as beta thalassaemia carrier in first pregnancy.)

- Example 5: 'It happens in our Pakistan because of dirt, because of disease, that's why there is thalassaemia. Some people catch it.' (Translated from Urdu. Mother of Pakistani origin, identified as beta thalassaemia carrier in first pregnancy.)

\section{Appendix 4. Partner carrier screening.}

- Example 1: 'I had my trust in my husband as well ... But I never knew how ignorant he was about all those things. He said he's $A A$ [not a carrier] - that he's OK. I think it's kind of believed to be AA is like when you're not weak, when you're not tired, you're not anaemic, you know, you're active, so that, I mean, you're a big man with big broad shoulders, with big bones, you know - you can do things that the women cannot do. So I think that, in his books, means, not being sickle, not having the sickle trait. But then he has it [the trait]. (Woman of Nigerian origin who is a sickle cell carrier and has a child with sickle cell anaemia.)

- Example 2: 'I knew sickle cell being mainly in the black community. And I don't know, he could have thought that I'd been dishonest ...You do look at the baby and you know that she is both of ours. But no, there could have been, if he wasn't as understanding, if he wasn't as good a man as what he is, then I dread to think ... I could have been black and blue by now and out that door with a newborn baby, nowhere to go. (White British mother with white partner, baby identified as sickle cell carrier through newborn screening. Mother also a carrier.)

- Example 3: 'To me it means that l've got a four-lane carriageway, l've got a child and I put him in one of them, and I know that in one of those a car will come fast ... This is $25 \%$ to me.' (White Italian couple, got married knowing they were both thalassaemia carriers, have tried preimplantation genetic diagnosis so far without success.) 


\section{Appendix 5. Communication of screening results.}

- Example 1: 'Well, I didn't know I was actually being tested for that ... and then I had a letter saying that I had the beta thalassaemia trait. And obviously I didn't know what that was because l've never heard about that before ... I was terrified, I didn't know what it was all about.' (White British woman. Discovered she was a beta thalassaemia carrier in pregnancy; partner not a carrier.)

- Example 2: I suppose if you've got that person on the line, you can actually ask questions straightaway. Whereas I had to ring up [following receipt of a letter]. If she hadn't have been in the office I wouldn't have been able to speak to her straightaway... But some people might not be that fortunate. And like I say it put my mind at ease that day.' (Mother of white British and Jamaican origin, son identified as sickle cell carrier through newborn screening.)

\section{- Example 3:}

Father: 'You almost wish that somebody would help you and sort of say, "Well, I think you should do this." But of course they wouldn't, they wouldn't say either way, "We think you should do this. We think you should do that." ... Sometimes I sort of wished that somebody had given us a guiding hand, because it was so hard to decide.

Mother: 'I feel to an extent differently. I don't think that any medical professional, I don't think they certainly can, and I don't think they should give you, push you in any direction at all. I mean, ultimately when you're talking about screening and what you will potentially find out about your unborn child could result in, in the end of that pregnancy, and that has to be a decision that only the parents take, without any guidance, I think, from, from any professional. (White British couple, both beta thalassaemia carriers, had prenatal diagnosis and decided to continue with affected pregnancy.)

- Example 4: 'They said get checked, everyone said get checked. And he [her husband] would not agree, he said, "We don't want to get checked." And there was [the counsellor], and she said that if the child has thalassaemia, then you can terminate such a baby, or it could be that it is not well or something. We said that we would not have termination. We thought that we will get checked, and we'll know, but we will not have termination.' (Translated from Mirpuri. Mother of Pakistani origin and Muslim faith, first child has beta thalassaemia major. Now regrets having had chorionic villus sampling.)

- Example 5: "I think I tried to prod them in a way, and say, you know, "If I have to go to termination, what is the steps?" They tried to be nice in a way, they tried not to go down that route ... I think they were trying to be neutral, but in a way if the patients want to know, then they should give us the whole works rather than shield us.' (Father of Vietnamese origin. Antenatal screening showed his partner carried beta thalassaemia and he carried haemoglobin E. Subsequent amniocentesis showed baby was unaffected.)

\section{Appendix 6. Religion, screening and diagnosis.}

- Example 1: 'I'm not praying for it but even if this child is SC [has haemoglobin SC disorder] I wouldn't say, "Oh no, I'm not having that baby." So there's no point in even doing any kind of tests or anything, so l'm just happy with what God's going to give me ... (Mother of Nigerian origin and Christian faith, knew from childhood she was a sickle cell carrier. Husband knew he did not carry $\mathrm{Hb} \mathrm{S}$ but did not know he carried $\mathrm{Hb} \mathrm{C}$ till their first baby diagnosed as newborn with haemoglobin SC disorder. Declined prenatal testing in next pregnancy.)

- Example 2: 'I didn't have the test because there wasn't any point in getting checked, because neither did we want to have a termination and neither did we think there was any point ... I left it to Allah ... The individual cannot do anything ... If we'd have terminated, then we wouldn't have our daughter. He [husband] says, "Okay, our daughter is troubled, but Allah has given her these troubles, and at least she is in front of our eyes." We don't have to regret that we terminated her.' (Translated from Mirpuri. Mother of Pakistani origin and Muslim faith, first child born with beta thalassaemia major, diagnosed prenatally by chorionic villus sampling. Declined prenatal testing in all subsequent pregnancies - three sons unaffected.)

- Example 3: 'I'm a Christian, I wouldn't have an abortion ... Other people would think it's the best way, termination would be best for them. So I think for each individual it's best to have the screening, both to know, because it's better to prepare - if you want to keep the baby, ... than not to be prepared and be shocked and, and sad.' (Mother of Congolese origin and Christian faith. Mother learnt through antenatal screening she was a sickle cell carrier, partner refused screening. Not aware she could have prenatal diagnosis. Baby diagnosed with sickle cell anaemia by newborn screening.)

- Example 4: 'I start from the principle that in life everyone has their crosses to bear. And for me, my first son, I've taken him up as my cross - which can be heavy sometimes. But at the same time I manage it because I love him. And in the life that I travel with him I can see the life of Christ. And that helps to lighten my burden. (Translated from French. Mother from Ivory Coast of Roman Catholic faith, first son diagnosed with sickle cell anaemia through newborn screening in France. Neither partner knew they were carriers before the birth). 